INTERDISCIPLINARIA ARCHAEOLOGICA NATURAL SCIENCES IN ARCHAEOLOGY

\title{
The Potter's Wheel in the Chilean Central Valley: A Long-Term and Contextual Perspective on Technological Change
}

\author{
Jaume García Rosselló ${ }^{1 *}$ \\ ${ }^{1}$ Department of Historic Sciences and Art Theory, ArqueoUIB Reserach Group, University of the Balearic Islands, Cra.de Valldemossa, \\ 07122 Palma, Spain
}

\section{A RTICLE INFO}

\section{Article history:}

Received: $29^{\text {th }}$ January 2021

Accepted: $9^{\text {th }}$ November 2021

DOI: http://dx.doi.org/10.24916/iansa.2021.2.12

\section{Key words:}

technological change

long-term analysis

social technology

ethnoarchaeology

ethnography

history

Pomaire potters

central Chile

\begin{abstract}
A B S TRACT
In this article the social and technological dynamics detected in the transition from hand-made pottery to wheel-thrown ware in a modern context is considered. The many different sources supplemented by fieldwork provide a long-term perspective and a depiction of its present consequences. It is specifically explained, how an indigenous, hand-made, domestic and female pottery-production system has turned into an essentially male, wheel-thrown and workshop activity.

After a series of significant events, the Indian village of Pomaire gained a reputation as a potter's village. The several changes underwent by its population as regards to pottery production makes it an interesting example to analyse the origin and development of a process of technological change which ended up with the displacement of women from pottery-making and the introduction of the means for mechanised production during the 1980s. Thus, the social and technical transformations which have taken place since colonial times (beginning of the $16^{\text {th }}$ century), for the potters of Pomaire are explained, enlarged on their history in order to contribute to a general reflection.
\end{abstract}

\section{Starting point}

In this article the social and technological dynamics in the transition from hand-made to wheel-thrown pottery in a modern context is considered. Source availability as well as fieldwork provides both a long-term perspective and a depiction of its present consequences. Here, it will be specifically explained, how an indigenous, hand-made, domestic and female pottery-production system has turned into an essentially male, wheel-thrown and workshop activity.

As a consequence of a series of significant social, cultural and economic events, the Indian village of Pomaire gained a reputation as a potter's town (Figure 1). The several changes undergone by its population with regard to pottery production makes it an interesting example to study the origin and development of a technological change process which resulted in the displacement of women from pottery-making

*Corresponding author. E-mail: jaume.garcia@uib.es and the introduction of mechanised production means during the 1980s. Thus, the social and technical transformations which have taken place since colonial times (beginning of the $16^{\text {th }}$ century), for the potters of Pomaire are explained, enlarged on their history in order to contribute to a general reflection.

The question of technological change and, particularly, the transition from hand-building to wheel production has been widely studied in archaeology (Arnold, 1989; Arnold III, 1991; Balfet, 1965; Deal, 1983; García Rosselló, 2006; Rice, 1987). Among the reasons posed for this change, "rentability" of the product and techniques may be mentioned. Questions such as the use of the potter's wheel to increase the volume of products and the consequent increase in income were frequently considered (Anders, 1994; Rice, 1987; González et al., 2001; Balfet, 1965; Arnold, 1985; Renfrew, 1978). On the other hand, it is unlikely to find in the literature any criticism of the direct correlation proposed between the use of the potter's wheel and the male workforce on the one hand, and the development of full-time specialised work on the other (Arnold, 1985; Balfet, 1965; 1981). 


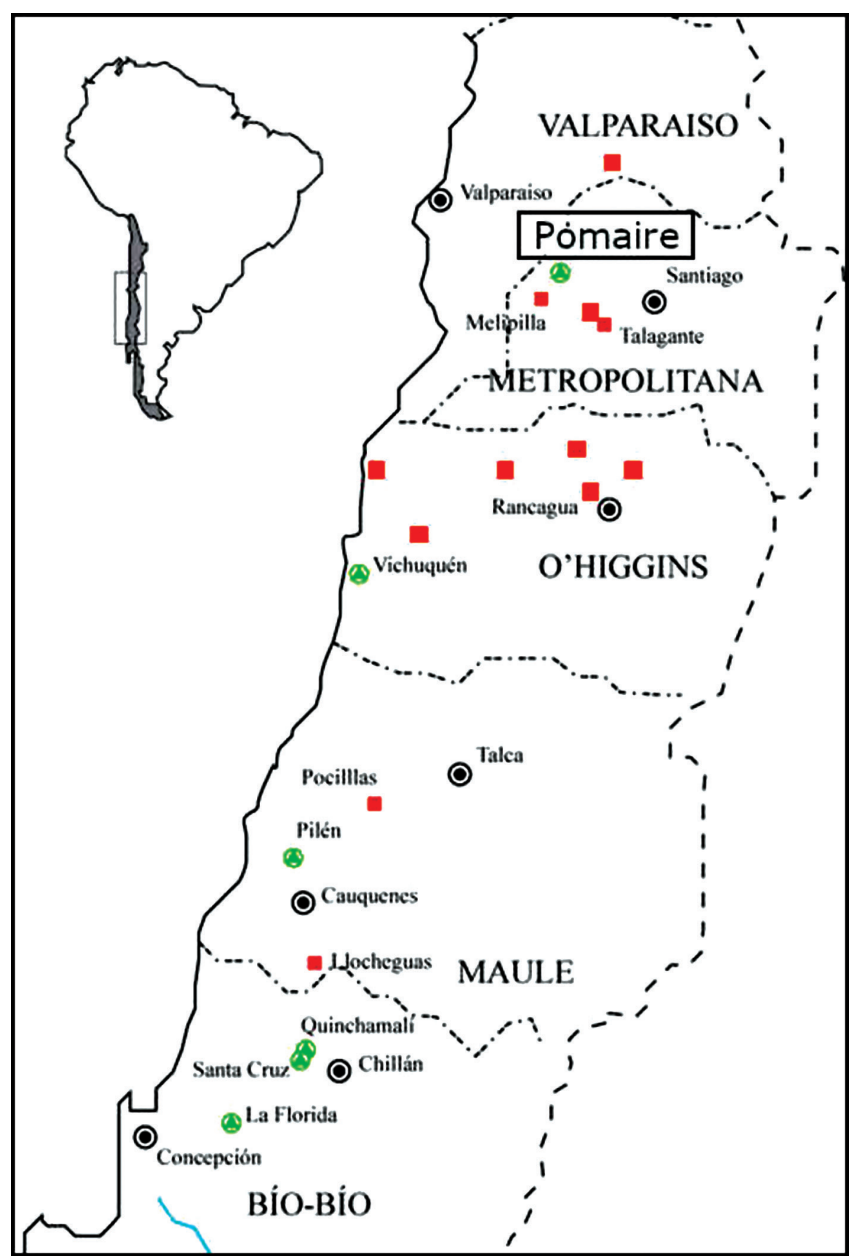

Figure 1. Map of pottery production and Pomaire situation. Author's design.

In this paper I do not disregard issues such as efficiency, rentability and economic value to explain the incorporation of the potter's wheel; rather, I want to highlight some reasons of a social and ideological kind which have not been generally explored as they should. That is, I aim to overcome the typical answer of modern industrialised society which simplistically correlates technological development and the new role of male potters with the increase in production and progressive specialisation.

Due to their peculiar development, the potters' villages in central Chile represent an excellent study case to provide a historical context and diachronic perspective to the technological changes produced in the last centuries in indigenous communities $\left(16^{\text {th }}-21^{\text {st }}\right.$ centuries $)$. Furthermore, they integrate them in the new social dynamics in the context of Chile.

Hence, I emphasise the long-term cultural processes (García Rosselló, 2008; Politis, 2015; Lyons and Cassey, 2016) to avoid producing an isolated and static ethnographic study case whose value is similar to fixed-frame photography. That is, I propose studying how material and cultural changes have taken place, as well as the long-standing processes involved, keeping in mind the social context in which they were generated and reproduced (García Rosselló, 2006; 2008; 2016).

\subsection{Research strategy}

The reports about Chilean pottery of indigenous origins are full of references relating to technological change (Graham, 1823; Valenzuela, 1955; Lago, 1971; Pérez, 1973; Valdés and Matta, 1986; León et al., 1986; Rebolledo, 1994; García Rosselló, 2006, 2008; Berg et al., 2014; García Rosselló, 2016; Montt and Lecrec, 2017; García Rosselló, 2019). For the last two centuries, a corpus of technical information has been created - which includes the organisation of production as well as the products created - and is of great variety when compared to other contexts (Sillar and Jofré, 2016). In the case of Pomaire, this corpus is considerable due to its privileged location. Founded between the capital city, Santiago, and its commercial port, Valparaíso, the village has received the visits of travellers and scientists alike. Furthermore, its products were distributed throughout the country.

Different kinds of documents are available for the colonial and republican periods $\left(16^{\text {th }}-21^{\text {st }}\right.$ centuries $)$, together with travellers' and erudite visitors' chronicles (such as Graham, 1823) and archaeological reports (Prado et al., 2015; Prieto et al., 2006). For the $20^{\text {th }}$ century, we can also resort to the large Chilean historiographic tradition (Sagredo, 2014), which preserved and disseminated most of the documents.

A number of folklorists (Valenzuela, 1955; Lago, 1971; Berg et al., 2014, among others) documented and described the craft traditions in Pomaire, either with a journalistic or scientific interest. Between the 1970s and 1990s, historians (Borde and Góngora, 1956; Bowen, 2007) and anthropologists from the Centro de Estudios de la Mujer (Centre for Women Studies) created an intensive program to compile life stories of rural women (Valdés and Matta, 1986; Rebolledo, 1994; De León et al., 1986). As a result, there exist a significant number of interviews for reconstructing the oral memory of women potters (Valenzuela, 1955; Valdes and Matta, 1986; García Rosselló, 2008; Berg et al., 2014; Montt and Lecrec, 2007), which could be informative for recovering the social and technical development in the village at the beginning of the $20^{\text {th }}$ century. However, two kinds of problems originate when processing this data: the chronological uncertainty of oral stories and the technical inaccuracy of both compilations and relations in regard to the pottery production.

This research incorporates the spatial analysis of modern workshops to understand transformations in organisation of space and architecture. It includes a revision of the materials produced and the tools used throughout time, the recording of chaînes opératoires and technical gestures, as well as an inventory of technological infrastructures and raw material sources.

Simultaneously, oral directed one-to-one and anonymous interviews with Pomaire sellers, potters and consumers provided valuable data for gaining an understanding of both the current situation and recent changes.

In most ethnoarchaeological research, the time perspective and explanations about technological change have been 
hardly considered, as in "It is frequently difficult to specify the chronology of these historical changes" (González et al., 2001). It is due to the difficulty in finding written historical sources and trustworthy oral testimonies (García Rosselló, 2008). Hence, our proposal for a "diachronic ethnoarchaeology" that combines different methodologies and where the data collected comes from a variety of sources:

- Ethnographic sources: ethnographic interviews, immersive observation.

- Documentary sources: censuses, chronicles, government documents, legislative acts, previous ethnographic research.

- Oral sources: interviews to reconstruct the recent past.

- Archaeological sources: spatial analysis, recording of materials and chaînes opératoires, studies of technological change, etc.

The strategy described here aims to provide an historical context and diachronic perspective for the technical and material transformations which have only been documented from an archaeological viewpoint so far (García Rosselló, 2006; 2007; 2008; 2009; 2011; 2016; 2017 and 2019). Hence, rather than presenting an analysis of pottery technology in isolation, I propose integrating it into social dynamics.

\section{Pottery production during the colonial and republi- can periods $\left(16^{\text {th }}\right.$ to $19^{\text {th }}$ century)}

With the arrival of the Spanish colonists to the south of the Cachapoal River (by mid-16 ${ }^{\text {th }}$ century) in the western Andes, the local population of the central Chilean valley was concentrated and confined in "Indian villages". Regarding pottery production, among other consequences, it led to the relocation of the population and the manufacture of large vessels to transport and store wine, wheat and chicha (Cobo, 1964, p.114).

Nevertheless, some documents describe the production of an indigenous utilitarian pottery typical of Spanish forms but hand-made rather than wheel-thrown (Valenzuela, 1955; García Rosselló, 2008). In fact, until the end of the $20^{\text {th }}$ century, rural women continued using the indigenous handmade techniques for pottery-making, adapting their products to the forms and needs of the Hispanic population and the new criolla cuisine (Valdés and Matta, 1986).

At the end of the $17^{\text {th }}$ century, the setting up of an ollería (pottery workshop) by the Jesuit Order in Santiago introduced vitrified wheel-thrown pottery (Prado et al., 2015). This workshop supplied the city and other regions with ceramics; however, its products are scarcely represented in archaeological contexts around the city of Santiago (Prado et al., 2015, p.252).

On the other hand, archaeological excavations at the Plaza de Armas and surrounding areas, also in Santiago, documented a high amount of indigenous pottery and a reduced amount of imported ware and local imitations of European manufacturers (Botto, in Prado et al., 2015; Prieto et al., 2006). A similar situation was recorded in the Crypt of the Cathedral, where imported ware is hardly represented.

The Jesuit workshop increased the supply of Hispanictradition pottery with wheel-thrown vessels, introducing bowls, plates, pots, large bottles and building materials in the city markets (Prado et al., 2015, p.252), as well as large jars, cooking pots and pitchers (Encina, 1945, p.268). Gradually, European masters introduced the potter's wheel, vitrification and double-chamber kiln and hired local slave manpower in their workshops.

The closing of the Jesuit workshop in 1767 implied the end of the ephemeral wheel-thrown local production. However, importation of table-ware gradually increased in the country (Henriquez et al., 2013) due to the global economic situation (Salazar, 2010) and the increase of maritime trade at the port of Valparaíso. It was also stimulated by china manufacturers established at Lota (AAVV, 1997) and Penco, around the 1930s (Márquez, 2014).

\section{Pottery in the $20^{\text {th }}$ century}

In colonial times, wheel-thrown pottery arrived to the rural estates from Lima, Panama and Spain. By 1930, the domestic market was still small, particularly in the estates; thus, peasants needed to produce their own domestic objects. This situation started to change around the 1940s when the estate owners introduced kitchen tools manufactured in urban industries and sold in the pulperías (rural grocery stores), opening up the market also to tenants (Valdés and Matta, 1986, p.45).

The incorporation of some pottery-producing rural areas to the market economy and the access to new communication roads (in some villages such as Pomaire, Quinchamalí, La Florida, Pilén, Vichuquén) extended the exchange networks of the rural production of tableware and cooking pots to neighbouring estates and urban markets (Bowsen, 2007; García-Rosselló, 2008). In this way, it favoured the continuity of manual pottery-production in these areas.

However, the beginning of the agrarian crisis led to the progressive disappearance of pottery-making in rural areas (for example, Llocheguas, Pocillas, Talagante, Donhiue, Machalí, Quitrico, El Copao, in Valenzuela, 1969; Barrales and Vergara, 2008; Chavarría and Vega, 2013; Lago, 1971).

In this context the first potter's wheels were introduced in some rural areas by the 1930 s to 1950 s: Pomaire, Nacimiento, Unihue, Pañul and Quinchamalí. It was initially restricted to the production of flowerpots, but gradually replaced handmade as well as imported ware and cooking pots (Valdes and Matta, 1986; Berg et al., 2014; Mont and Lecrec, 2017).

\section{Indigenous rural pottery in Pomaire $\left(20^{\text {th }}\right.$ to $21^{\text {st }}$ century)}

The production of hand-made utilitarian pottery continued for several centuries in the central valley (Figure 1). Despite 
some changes in the labour organisation and subsistence base, it was still a familiar part-time pottery production, female in nature and of an indigenous tradition (García Rosselló, 2008; 2017). These products were adapted to the criolla cuisine and exchanged for vegetables and fruit in the nearest farms. However, technological strategies were essentially shared by all women potters in central-southern Chile (García Rosselló, 2009; 2011).

Women were basically in charge of the house chores and stayed at the village, working in pottery-making and in small farms. In many families, husbands and children were responsible for obtaining the raw materials: they carried the clay in carts and brought animal dung and firewood from the estates where they worked (Graham, 1822; Valdés and Matta, 1986).

\subsection{Learning}

In Pomaire, girls used to learn by observing and imitating both young and adult women in their household, under the supervision of the eldest potter during the whole productive process (Vidal and García Rosselló, 2010). From a technical perspective, such practice combines two strategies: a learning process defined by the level of difficulty implied in the different stages of the technical process, and also on the manual dexterity demanded by the size and form of the pieces (García Rosselló, 2017; Calvo et al., 2015).

The learning process typically started when the girls were about seven to ten. Having participated in the family production for years - collecting and preparing the clay - the girl started to combine kneading and polishing with the modelling of small objects and toys (Valdés and Matta, 1986, p.84). Hence, from the very beginning, the apprentice helped her family and was socially integrated through the practice, while incorporating other values from her daily routines as well.

The chaîne opératoire consisted in:

\subsubsection{Collection and preparation of raw materials}

The clay (greda) was collected from a nearby hill (La Cruz) and transported to the house in carts. It was kept in water for approximately 15 days (pudrir la greda). "We soaked it in the house. So, no, we left the greda to rot. We kept it soaking for 15 days" (Juana Mendoza, in Montt and Lecrec, 2017, p.43).

The sequence started by eliminating from the clay the larger impurities by hand and mixing the material with water to be later kneaded. This process was repeated daily (according to Ester Guzmán, in Valdés and Matta, 1986). Occasionally, the bare foot used to knead the clay was introduced into the water to continue the process (Valenzuela, 1955, p.20). No temper material was added. "When we arrived home with the greda, we put it to soak and later we kneaded it. We had to knead it daily, a leather-weight of greda. Some time ago, the greda was kneaded on a piece of leather, animal leather; it was kneaded with a foot (...) " (Esther Guzmán, in Valdés and Matta, 1986, p.82).

\subsubsection{Modelling and primary surface treatments}

Before modelling, a ball was made and compacted between the hands. It was later flattened to a uniform thickness
(Valenzuela, 1955, p.24). This disc was used as the base and the support of the walls. It was gradually given a conical shape (hacer el canco) that was placed on a square wooden table resting on the potter's lap. Just before modelling started by coiling, a layer of fine sand was added to avoid the clay getting stuck "the potter takes a piece of clay and, carefully kneading it, turns it into a large coil which is immediately added to the stumps just mentioned" (Valenzuela, 1955, p.25). Both the form and the number of coils varied depending on the kind of vessel produced (cooking pot, paila, large jar, etc.). The potter scratched the surface with a concave gourd (mate), opening and stretching the recipient from inside (matear). To soften the border, they pressed a piece of leather (cordobán) between the hands and applied horizontal swinging movements (Valenzuela, 1955). "They formed a greda ball, which was left to rest for some days, covered. After that, they started to shape it. The canco was a kind of clay cone whose size depended on the approximate shape they were planning to do: a kilo for a large jar or a cooking pot, two kilos for each piece. They modelled it; they were mateando it. They used a mate of calabash in those days" (Lucho Olivares, in Montt and Lecrec, 2017, p.93).

\subsubsection{Secondary surface treatment}

They started polishing the pot (pulir) with a river pebble. Once the pot was shaped, it was left to dry, and later covered with a coat of slip and polished again. They frequently added some greasy liquid to seal the pores of the pot (hen stew or infundia de gallina) after the reddish slip (colo) had been applied to the whole surface (encolar). The clay slip was collected from a hill some $70 \mathrm{~km}$ distant (San Cristobal), soaked until the liquid turned thick enough to be ground on a stone (García Rosselló, 2019) and applied to the pot.

\subsubsection{Firing}

Firing took place in the house yard. The vessels were placed on a base of firewood piled up as a bonfire and covered with new logs and animal dung to preserve the heat inside the structure. "The earth was covered with animal dung mixed with eucalyptus leaves; a bed was made to hold all the greda, which was later covered with dung" (Esther Guzmán, in Valdés and Matta, 1986, p.86). They could also build " a layer of firewood and over it, dried bull dung. The ware is piled on top, all piled up, the large cooking pot underneath, the large paila, and the smallest ones on top. Quite high was the pile. They set light to it in many places and let it burn all afternoon" (Teresa Muñoz, in Valdés and Matta, 1986, p.225).

\section{1930-1950. First workshops and non-specialised subaltern work}

In a rural context where a monetary economy hardly existed, some villagers coordinated the non-monetary exchange of pottery in the nearest estates with annual trips to sell the 
ceramics at the Cardonal market (in Valparaiso city) and the sanctuary at Lo Vázquez.

For this reason, some started to model pottery (loza) all year long and accumulated the surplus for the family's annual sales (Valdés and Matta, 1986).

By the 1920s, the husband's collaboration had become more frequent: they kneaded the clay and built the bonfire. Although pottery-making continued as a domestic activity, there were some temporary and flexible associative strategies as well. The medierías system, an association of two women where income was equally distributed, was frequent among adult sisters or single women living in the same household. This association conditioned labour division and specialisation, which depended on the vessel form and the ability of the potter for the different technical tasks. So, the more expert ones used to build the pots and the less experienced ones dedicated themselves to surface treatments (Teresa Muñoz and other potters, interviewed by the author; Valdés and Matta, 1986).

The mingacos of pottery were also a type of associative work. It consisted in buying a high volume of pieces to be polished collectively in the buyer's house. Following this idea, in the 1920s some potters' houses developed as small workshops, introducing paid labour. They hired men to collect and knead the clay, or to prepare firing structures. Similarly, other women potters were responsible for modelling (Carmen Álvarez, in Valdés and Matta, 1986, p.81). Many women worked in other potters' houses (Olga Salinas, in Valdés and Matta, 1986) which had the facilities for pottery-making. Child labour was also present in this organisation (Valdés and Matta, 1986, p.84). Alternatively, potters could hire workers for agricultural activities and to collect clay (Mercedes Rosas, in Valdés and Matta, 1986). This system developed into a strategy where groups of two to three labourers visited several houses to knead the clay.

\subsection{Learning}

With the 1920 regulations stating obligatory schooling until the age of 13, which coincided with the first workshops in the village, pottery learning became more frequent when women were adults, at the age of 15 . When the mother worked as a paid labourer for another woman, her daughters usually joined the group to produce miniatures which were sold and accepted by the potters. The apprentice, free from doing auxiliary tasks such as kneading and firing, could now concentrate in learning the manual gestures for modelling. She also received a salary for collaborating in polishing and selling her toys and miniatures (García Rosselló, 2019).

The technological changes in the chaîne opératoire consisted in:

\subsubsection{Collection and preparation of raw materials}

The journeymen hired for agricultural activities also collaborated in some stages of the pottery-making process, such as clay collection in the hills (Mercedes Rosas, in Valdés and Matta, 1986). In fact, a team of men would go from house to house kneading and preparing the clay (wedging) and even searching for fuel and making the bonfire. Male participation in pottery production was then limited to relatively unspecialised tasks which did not demand an active participation in the learning process and needed little or no supervision by a women potter (García Rosselló, 2016).

\subsubsection{Modelling and primary surface treatments}

Regarding the modelling stage, technical manual skills and operations did not change, although some potters began to specialise in just one phase of the process: they worked only in raw material collection and preparation, or handled the modelling and firing, for instance (Valdés and Matta, 1986; Montt and Lecrec, 2017; García Rosselló, 2008, interviews by the author).

\subsubsection{Secondary surface treatments}

Many women work in the houses of other potters who have the facilities for pottery-making. They were frequently hired for the last stages of surface treatments such as polishing (Olga Salinas, in Valdés and Matta, 1986, p.81).

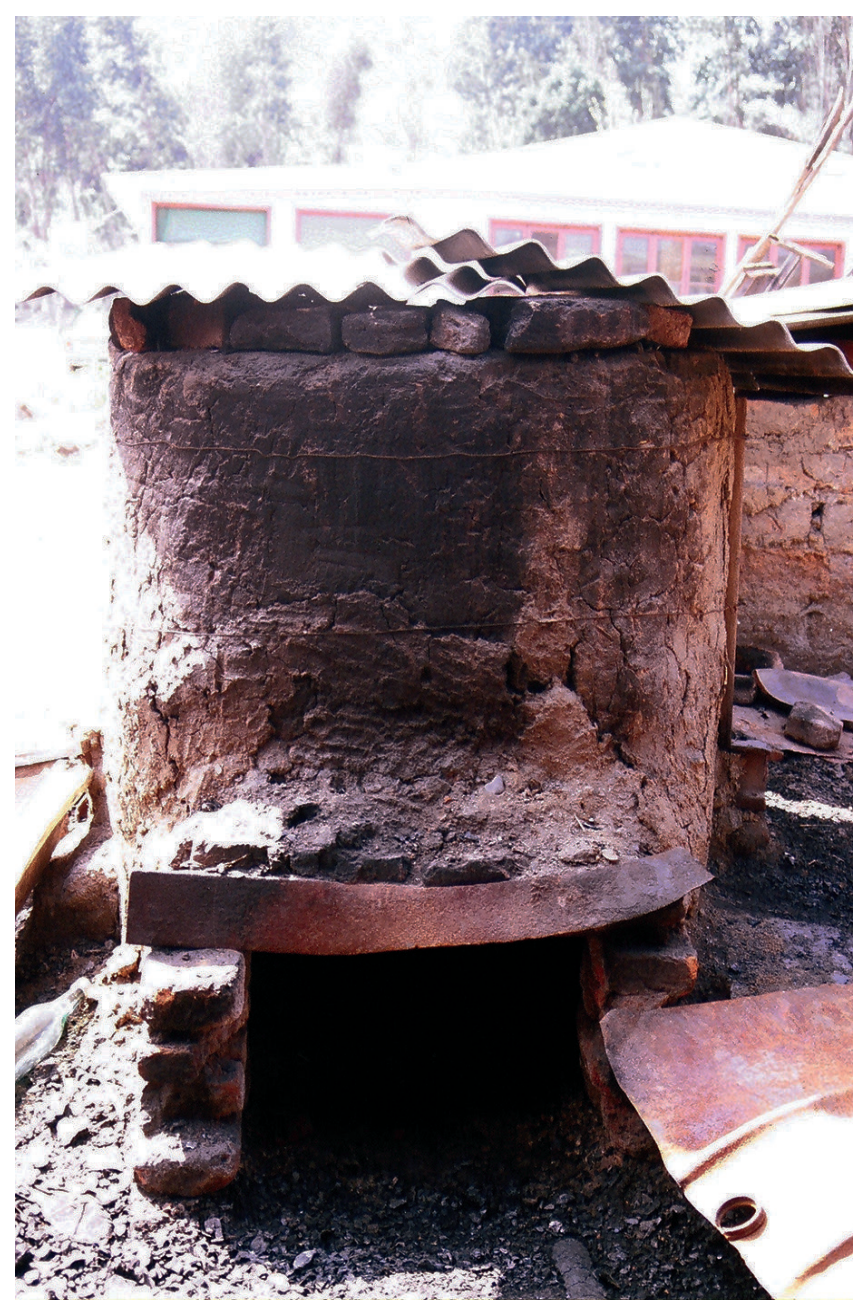

Figure 2. Circular kiln. Author's photograph, 1999. 


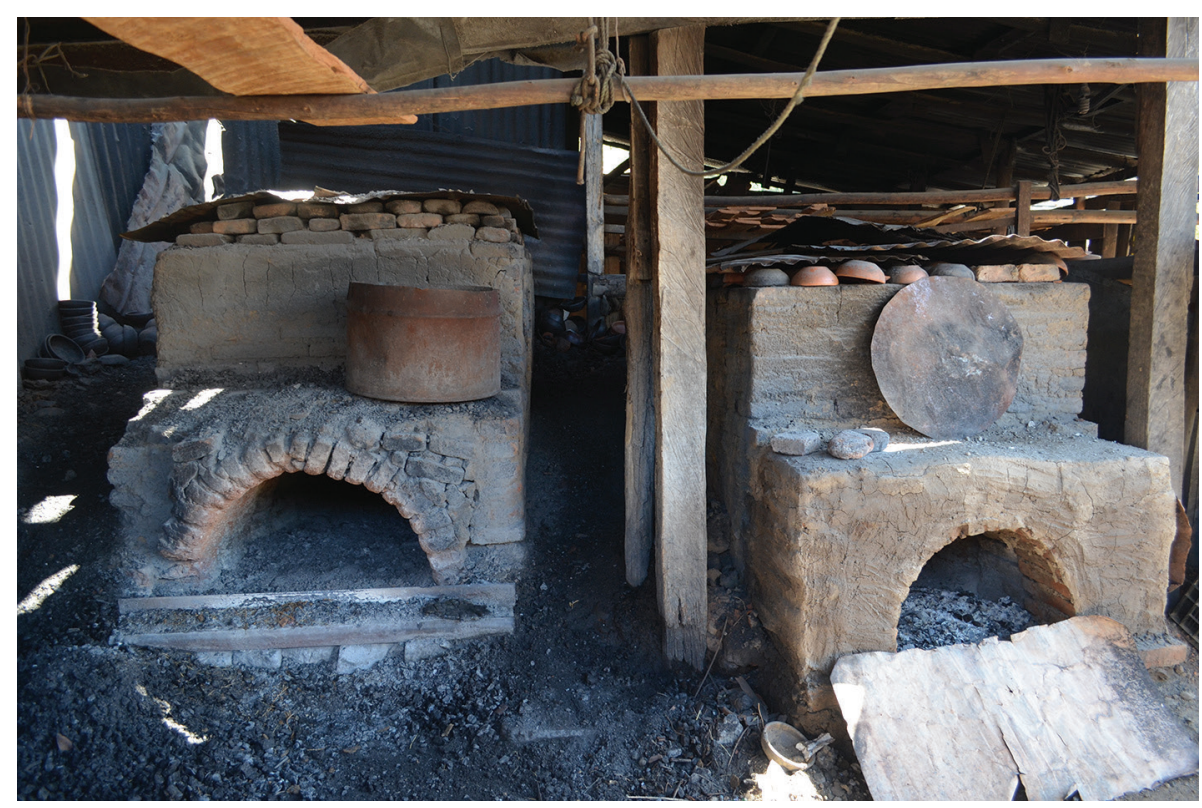

Figure 3. Square Kiln. Author's photograph, 2018.

\subsubsection{Firing}

Around 1930, Ernesto Ordoñez built a one-chamber kiln (hornilla) to fire the flowerpots he had thrown on his potter's wheel (Figures 2 and 3). Born in San Antonio, he moved to Pomaire after marrying Esther Ahumada (Valdes and Matta, 1986; Valenzuela, 1955; Berg et al., 2014; Mont and Lecrec, 2019).

The kiln created by Ordoñez had no parallels in the area, neither for flowerpots nor vessels. It was his own invention and consisted of a single-chamber tubular kiln of a circular plan with no upper cover (Figure 2). Fuel and pottery were separated by a simple rack and the $20-\mathrm{cm}$-thick wall structure built with ordinary bricks was covered by a coat of wattle and daub (Valenzuela, 1955, p.22). This kind of kiln became popularised in the region by 1950-55 (Valenzuela, 1955; Tomas Lago, 1971).

Thus, by the mid-1950s, every potter had a similar kiln in their backyard or even two or three (Figure 3), as they considered that they allowed them to "work less and fire good ware, [so] everybody started to do it that way" (Teresa Muñoz, in Valdés and Matta, 1986, p.225; Valenzuela, 1955, p.22).

\section{1955-1975 Consolidation of specialised workshops}

The origins of the mechanisation process in Pomaire can be dated to around 1930, when Ernesto Ordóñez introduced the single-chamber kiln and the first potter's wheel. However, while the kiln completely replaced surface bonfires in the village, the use and knowledge of the potter's wheel was not extended until the 1960s, together with the grinding machine (García Rosselló, 2016).

Women potters usually decided to hire itinerant potteryturners who modelled the basic forms of the pieces. The women later decorated, polished and slipped these pots. The potter's wheels, generally owned by women, were fixed in the workshops (Valdés and Matta, 1986; García Rosselló, 2008; 2015; interviews by the author).

In time, this process generated the coexistence of different technological strategies and systems of organised production in the village. In 1973, out of 275 potter families in Pomaire, 132 had a kick wheel and 143 worked hand-made pottery (Pérez, 1973). It means that $48 \%$ of the families already used the potter's wheel, while the remaining 52\% continued working by hand, just using the turntable in some houses. At the time, $47 \%$ of the families sold their unfired production to other groups who had kilns (Pérez, 1973). This situation may be related to two related phenomena:

a) The presence of pottery-turners (cortadores) who earned their salary by throwing pots (either at a women potter's house or in their own workshop).

b) The work of journey-women who polished and finished the wheel-thrown pots.

\subsection{Learning}

Between 1952 and 1973, the existing learning networks and systems of knowledge transmission were transformed. The Pomaire population grew $61 \%$, while the average population growth rate in the country was $49.7 \%$. The numbers continued increasing, reaching a sum total of $78 \%$ in 1992 and $50.2 \%$ at the national level (elaborated from Pérez, 1973). This population growth may be explained by the early migration of women and men from the village to the city in the 1920s, and their return in 1950-1960. The introduction of these women in pottery-making activities brought about new ideas which were presented in innovative ways, as well as a higher flexibility for adopting motor patterns different from traditional practices, as they had not participated in the learning process during childhood. Hence, the origin and tolerance of these potters facilitated the elaboration of new types - such as miniatures - and the adoption of innovative 
techniques and systems of labour organisation associated with the use of the potter's wheel (García Rosselló, 2019). The new male actors were also using the potter's wheel, and they created their own learning networks, which were parallel and different from the traditional ones in the central valley (García Rosselló, 2017). Now, women potters did not completely control the learning process - as new knowledge transmission networks had been generated. In fact, women kept working on the technical tasks transmitted in the traditional learning model from mothers to daughters. They included surface treatment, decorations and addition of secondary elements (García Rosselló, 2017).

While the previous technical strategies still continued, a series of changes in the chaîne opératoire were introduced. They were interconnected and resulted in the mechanisation of production:

\subsubsection{Collection and preparation of raw materials}

None of the potters interviewed could specify whether the introduction of the grinding machine (Figure 4 and 5) was prior to or contemporary with the popularisation of the potter's wheel. In the women's recollective memory, the decantation basin and the grinding machinery were needed for the finer clays used in some items such as miniatures (interviews by the author).

In any case, the privatisation of the traditional clay sources on the hill forced them to use lower quality material from the valley around Pomaire. However, despite the privatisation, the potters with less economic resources continued exploiting it, while others extracted the clay by digging ditches in the fields around the village (Valenzuela, 1955, p.20), a strategy even used in 1984 (Esperanza Ahumada, in Valdes and Matta, 1986, p.84).

In order to wedge these clays, some families introduced grinding machinery and decantation basins (Figure 4 and 5). In the 1980s, Esther Guzmán (in Valdés and Matta, 1986, p.248) described the process in these words: "The machine is owned by the wealthier people: these three people who bought it produce flower-pots. First, they soak the clay in a hole and then they introduce it into the machine. They have to pay for the barrow load to receive it at home. A man is in charge". Similarly, Orlando Malhue explained in 2012: "They sell us the greda according to our needs: coarse for large jars, and regular for smaller things" (Berg et al., 2013, p.200).

\subsubsection{Modelling and primary surface treatments}

During the mechanisation process, turntables and kick wheels were finally popularised (own observation).

\section{a) Introduction of the kick wheel}

In the beginning, the potter's wheel was not available for everybody; it was an exclusive technique which was hardly shared. The only pottery-turner living in Pomaire, Ernesto Ordoñez, worked in the shadows throwing flower-pots and did not socialise his knowledge.

By 1950, new turners arrived in the village (René Guerra and Pedro Meza) from the south (probably from the potter's village of Nacimiento) and Puente Alto, near Santiago. They were hired by a family to produce flower-pots and also worked secretly, preventing any imitation (O. Malhue, in Berg et al., 2014, p.203).

At the same time, Ernesto Ordoñez's son continued his father's tradition. It was then that the rest of the village started to consider the potter's wheel from a different perspective, as it was used by a man born in the village. Consequently, some of the inhabitants were interested in learning the technique and tried to build the first potter's wheels.

Both men and women potters considered that around 1960-1966 the first local potter's wheels were already in use: "In 1966, the first pottery-turners started to appear and, as everything takes its time, you need somebody to throw

Figure 4. Ancient decantation basin and the grinding machinery. Author's photograph, 1999.

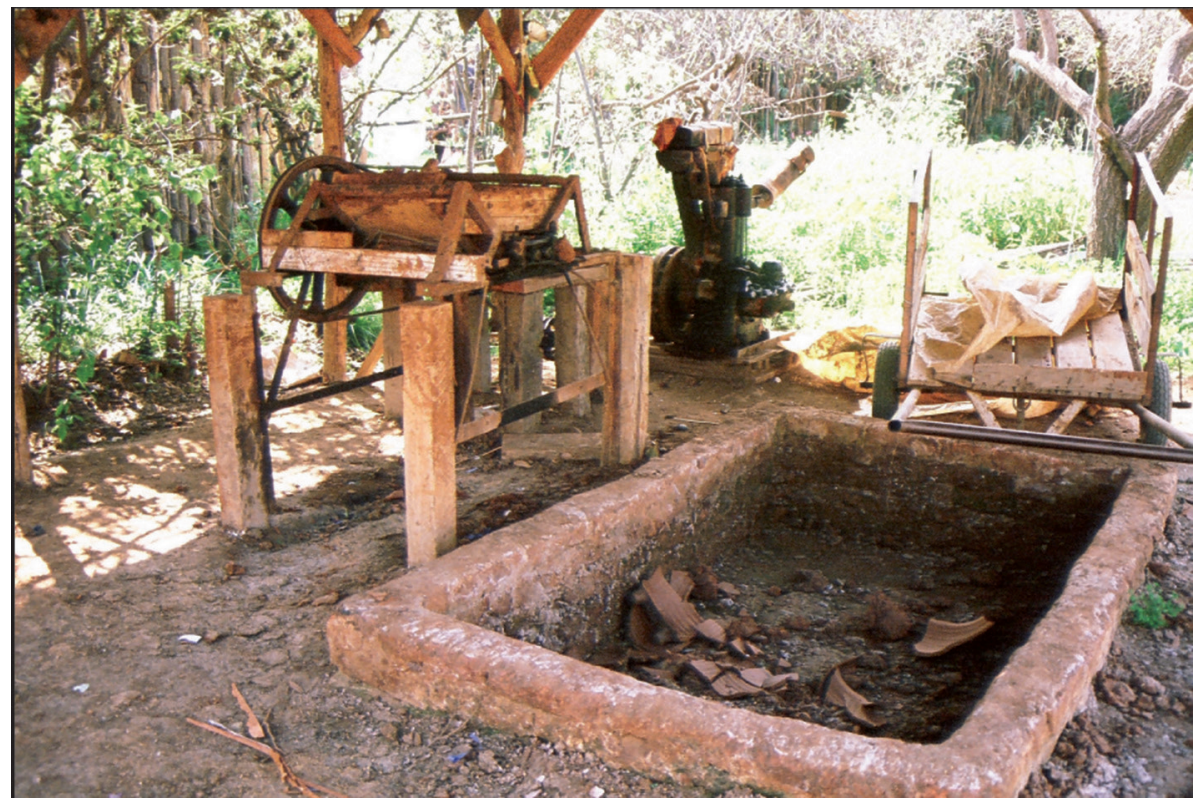




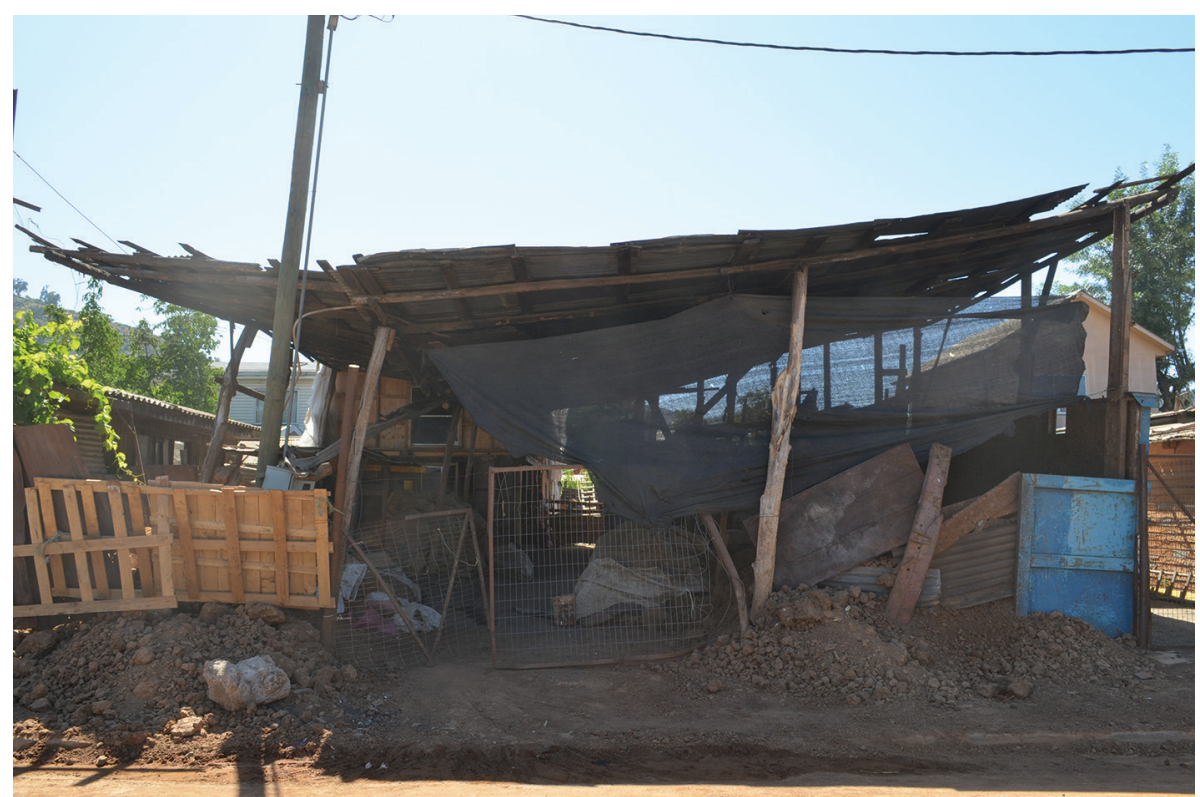

Figure 5 Clay storage and processing workshop. Author's photograph, 2005

the pots but you have no potter's wheel" (Juan Domingo Riquelme, Berg et al., 2013, p.168).

David Pardo remembers having seen a potter's wheel for the first time around 1960, when he went to buy clay at another potter's house, Raúl Riveros: "I used to buy the greda there. And I saw how they worked and I immediately started to use it" (Montt and Lecrec, 2017, p.49).

Víctor Vera clearly explains the private and secret nature of the potter's wheel when it arrived in the village, and the role the house yards had in making it visible: "A man arrived, almost in this same street, and the neighbours used to come to the yard and think: 'that man is making twelve jars as usual', when suddenly that friend sees that the twelve jars were not there... 'What is he doing?' 'Magic?'. He sees a lot of jars all of them even, and the man with the door closed, the room closed. He peeps through a crack, sees inside the room, and sees a small potter's wheel" (Montt and Lecrec, 2017, p.60).

In the beginning, the adoption of the potter's wheel was limited due to the restricted access to the productive space and the lack of machinery and technical skill. When the wheel started to be visible and practical, the local population imitated it using local innovations such as the kick wheel (Figure 6).

Nevertheless, this technical change was not possible until the potters learnt the new technology and had direct contact with the machinery. This was the origin of the local development of mechanisation and a technical transmission which was not restricted to a few local specialists.

These pioneer attempts were highly rudimentary and demonstrated that they had not managed either the mechanism nor the technique: "he built a potter's wheel: the upper disc was made with an old record-player and he made it there, I don't know, he imagined that (Juan Domingo Riquelme, 2012, in Berg et al., 2013, p.169).

The adaptation to the potter's wheel and the technical learning implied were a significant local innovation: "We built the potter's wheel, we didn't know how to rotate it, we didn't know how to use it; but then, we shared ideas with several artisans and we learnt, learnt to throw, to be masters. I was one of the first five cortadores [turners] in Pomaire" (Orlando Malhue, in Berg et al., 2013, p.202). This change demanded fast learning processes, as opposed to the strategy followed in hand modelling: "we searched for a master and built a potter's wheel (...) in about a week I learnt to cortar" (Juan Domingo Riquelme, 2012, in Berg et al., 2013, p.169), "the kick potter's wheel is good to learn the craft, because the speed can be regulated by the master himself' (Enrique Osorio, in Montt and Lecrec, 2017, p.117).

The new machinery as well as the technical gestures and operations used were adapted to elaborate the traditional pottery forms women used to model by hand (Figure 7). Thus, the use of the potter's wheel was accommodated to the local types. The forms were generally plates, flower jars and similar vessels (Figure 8): "almost everything that is rounded-plates, ovens, little vessels - is wheel-thrown (...)" (Ester Guzmán, in Valdés and Matta, 1986, p.241). David Pardo, considering modern times, explains the process in this way: "With the potter's wheel you can only create forms with a circular base, because the disc that rotates and is impulsed by the feet or an engine (several potters have adapted a washing-machine engine) restricts the work. After some 30 seconds, when the piece is ready, the master 'cuts' it with a nylon fishing thread, detaches it from the machine and puts it to dry. Other processes must be applied later" (Montt and Lecrec, 2017, p.49).

There were itinerant pottery-turners who went from house to house throwing (cortando) the base form of the pots, using the potter's wheels women potters had at home: "There are cortadores who work in their own house, with their potter's wheels, but it is not convenient because, you see, we would need to take them the greda, and then go to collect it. It is better if they come here" (Ester Guzmán, in Valdés 
Figure 6. Traditional Pomaire kick wheel. Author's photograph, 2018.

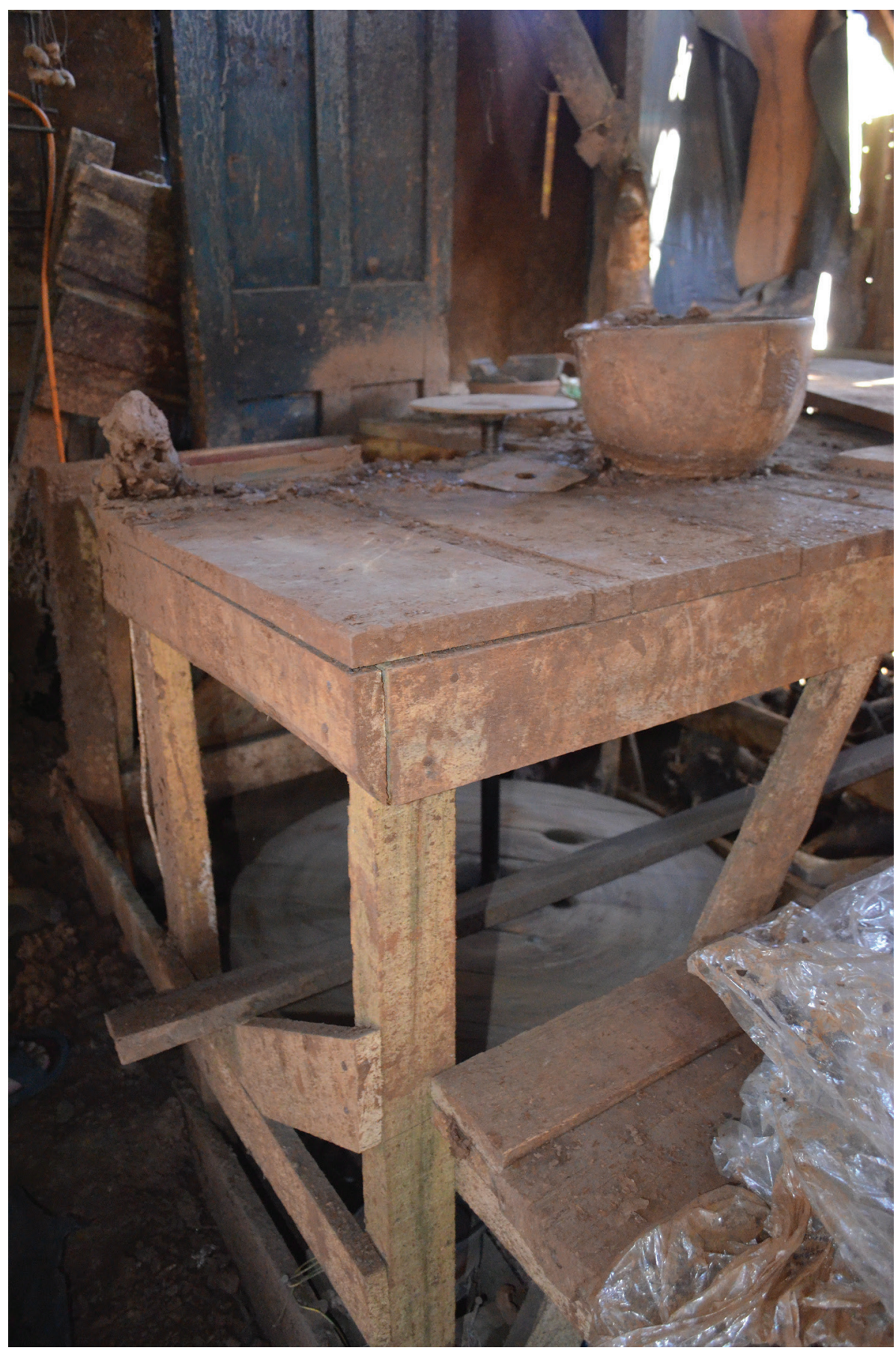

and Matta, 1986, p.241). In this way, women continued controlling the productive process strongly related to the domestic space: "I go to many houses. I design what they ask for. Here they throw cooking pots, there pailas, grills. Some time before, we threw mainly flowerpots, but now it is lost, because of plastic" (Enrique Osorio, Montt and Lecrec, 2017, p.117).

At the beginning there were only 5 pottery-turners (cortadores), who combined the work in their own workshop with visits to other potters' houses: "As we did not have [a potter's wheel] we went to a turner's house, we took him the greda (...) and we asked him to do the pieces there". The job of the cortadores was part-time, supplemented by other activities: "My father had a place. I made the pottery. We used to work with cured meat in winter, and in the summer, we made pottery in his place. His brothers learnt there." (J. Riquelme, in Berg et al., 2014, p.169).

\section{b) Introduction of the turntable}

A few references describe the existence of turntables by 1930: "At this time, there were no potter's wheels but rather a disc which was moved with a screw. But not an actual kick wheel. There were no cortadores, everything was handmade" (Rosa Torres Astorga, in Valdés and Matta, 1986, 

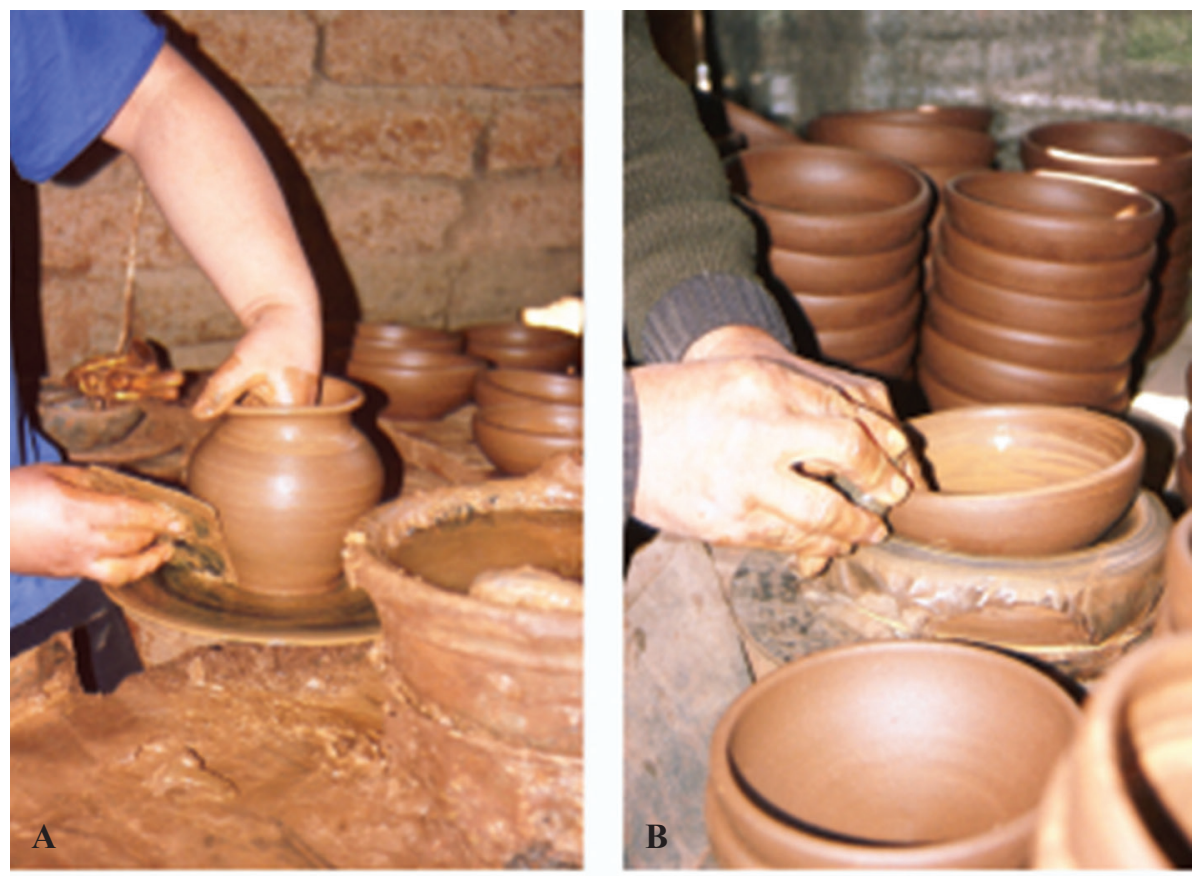

Figure 7. Handmade and pottery wheel technical gestures. A - building pot with potter's wheel and tool. B - Surface treatments with potter's wheel and river pebble. C - Traditional hand-made surface treatments. D - Traditional hand-made building pot. Author's photograph, 1999-2007.
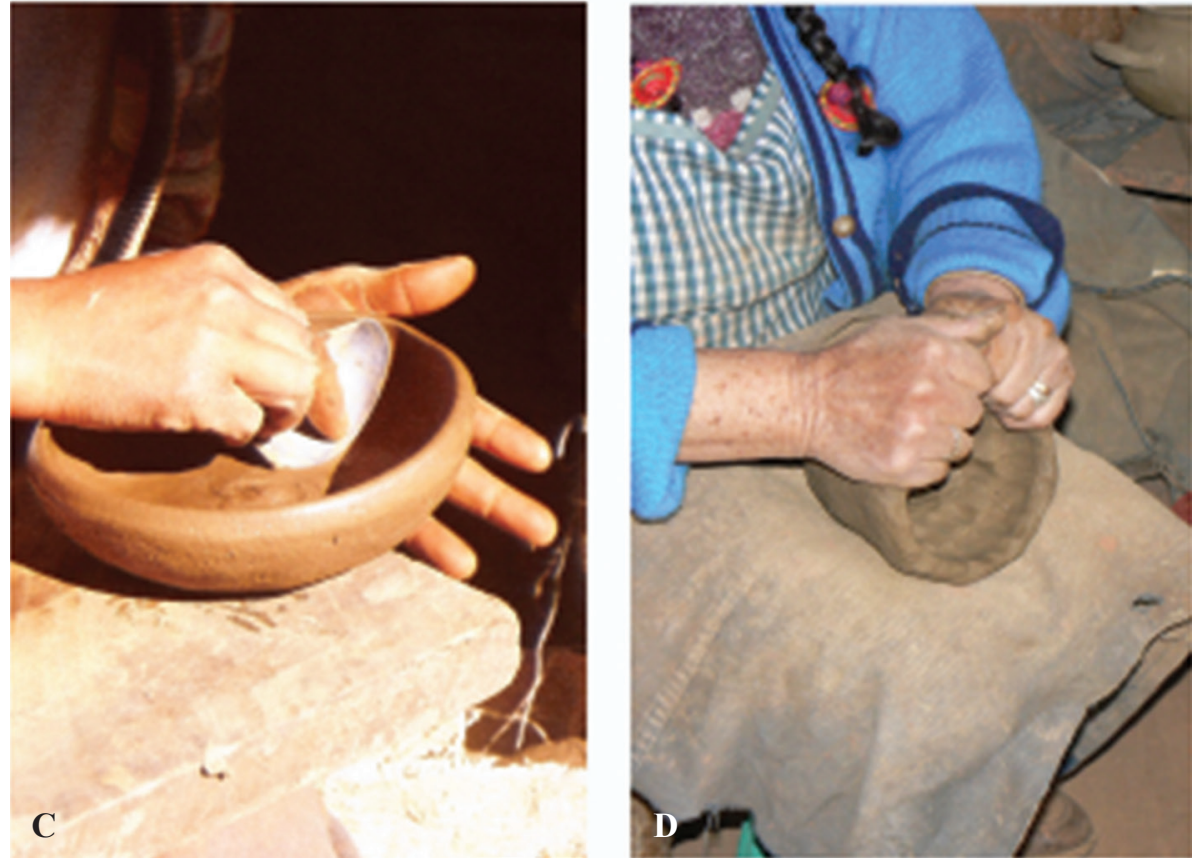

p.215). "They used small potter's wheels which were rotated by hand. Those have always been used. Some cancos were modelled there, some cones, which were left to dry" (Norma Riquelme, in Valdes and Matta, 1986, p.305).

However, available documentary references demonstrate that most of the population continued modelling on a wooden table until the 1950s-70s and even later. Many reports indicate the use of turntables by women potters by the 1960s (ayuda manos, according to Víctor Vera, in Montt and Lecrec, 2017, p.60). Before this machinery was in use, they resorted to a wooden box. In fact, the first turntables recorded were "an apple wooden box, a broomstick and a wooden plate on the flywheel (...) until someone included a button. And you sit here and it started in that way" (Víctor Vera, in Montt and Lecrec, 2017, p.60).

The turntable was a tool, which prevented working on the floor, a position which forced the potter to rotate around the piece. Juana Mendoza clearly explained it "now there are turntables: instead of having to go round the pot, now you turn the turntable" (Montt and Lecrec, 2017, p.60). On the turntable "they put the canco [inverted clay cone which is given a form] with a wet base so it "rotated on its own" (Patricio Muñoz, in Montt and Lecrec, 2017, p.37), "She put it in position imitating a bell and started to matear it. 
Figure 8. Pomaire traditional pottery forms today. Author's photograph, 2015-2018.
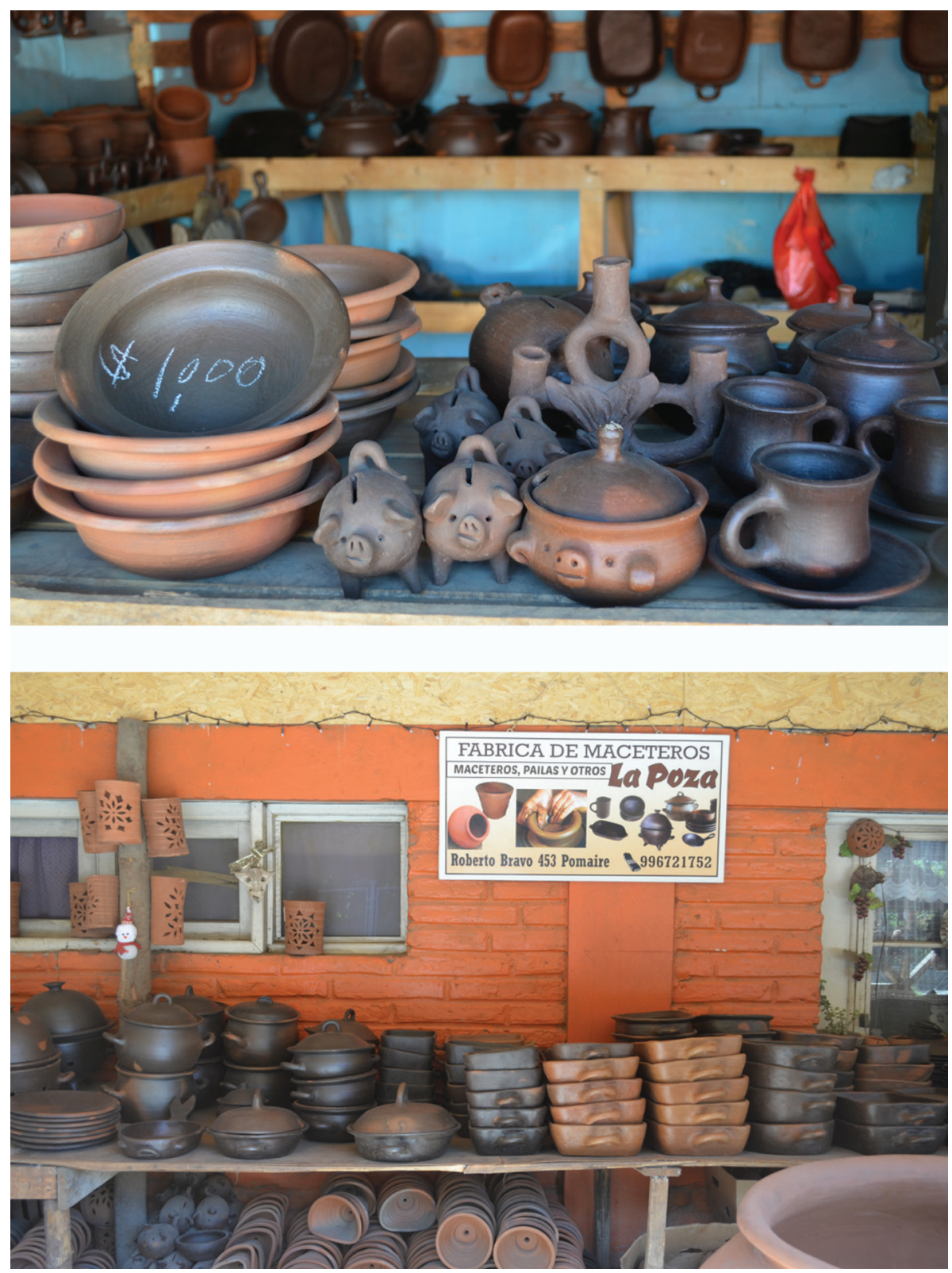

Then, the hand helped her, she did not have the piece on her hand any more, she was mateando" (Víctor Vera Montt and Lecrec, 2017, p.60).

Available accounts, documental records and field work describe the generalisation of the turntable among traditional women potters. It was a local innovation with high variability: some were made of iron or wood, and they were either square or circular (Figure 9; see, for instance the Photographic Archive of the research group "Género, historia y ruralidad" at the CEDEM).

\subsubsection{Secondary surface treatments}

In this process, when the potter's wheel was used to shape pots, the man threw the base forms and the woman orejeaba (fixed the handles), encolaba (applied slip) and polished the pots using flat stones and pieces of leather (Peters and Núñez, 1999, p.37).
On the other hand, the women potters who had a turntable could either continue doing the whole process or dedicate themselves to the secondary surface treatments.

For women potters, the process after forming the pot was extremely important before the arrival of the kick wheel and the introduction of men in the modelling process. This importance was reflected in the terminology used: the "armado" (building) referred to modelling while "componer" (composing) was the finishing.

In fact, it was a context where production was focused on pottery decoration: they made utilitarian forms, which were later decorated with plastic applications.

\subsubsection{Firing}

Firing did not change during this period. The procedure is even used nowadays, although in the last decade's gas and electric kilns started to be generalised. 


\section{Conclusions}

The early specialisation of potters at Pomaire due to the annual sale markets had a dynamising effect in transforming labour organisation. It implied the arrival of specialised workers and the creation of differentiated spaces in their houses. The first workshops developed under the leadership of the wealthier women potters. Other women were then hired for modelling and finishing, and some men would fulfil auxiliary tasks such as clay collection, kneading and preparation of the firing place, together with the surveillance and provision of firewood.

Hence, the activities related to the learning process, which had traditionally been in charge of the youngest potters, became standardised and made by journeymen. Eventually, it would create the appropriate conditions for changes in knowledge transmission networks and in the learning process. Another reason for these changes was the girls' access to formal education and the massive arrival of a foreign population to the village. Both groups would learn the craft in their adult age, with the consequent flexibility and freedom for the introduction of new techniques.

A thorough analysis of the sources used indicated that the economic rentability and technical efficiency were not the only reasons for the technological changes implied in the introduction of the potter's wheel.
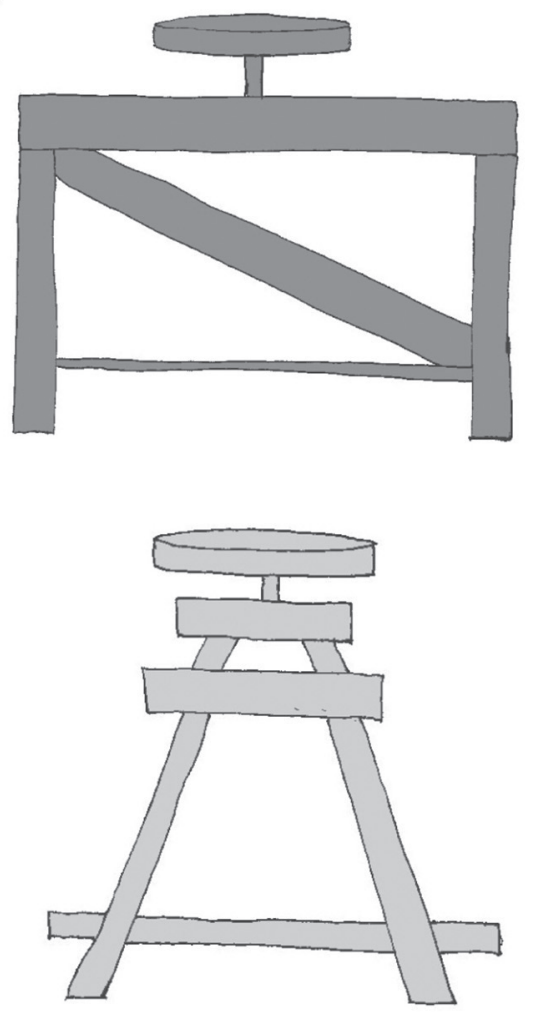

Figure 9. Types of turntables. Author's design.
However, the reduction of the working time it was identified with, and the subsequent increase in production, did not produce a net increase of the monetary income in the Pomaire population, who had just recently entered the market economy. Rather, and more importantly, it meant the incorporation of all the family members to the productive process and the origin of their new organisation system.

Rentability and efficiency were not the only factors which may participate in the generalisation of the potter's wheel among the population. Other reasons, such as the reduced geographical marginality due to the popularisation of some means of transport, the role played by immigrants, ideology, the local situation and the transformation of learning systems also played a significant role in the flexibility and acceptance of new ideas, techniques and labour organisation systems.

In this sense, the outcome and generalisation of the potter's wheel was related to the end of a process defined by social, ideological and economic changes already taking place in the village. The consolidation of male work and the generalisation of the potter's wheel were the material expression of these changes rather than the engine which initiated them.

The introduction of the potter's wheel was possible because the population had already incorporated technological changes in raw materials preparation and in the firing process, as well as in the productive modes and labour organisation.

The data discussed here evidenced the need to distinguish between the incorporation of a "foreign" innovation, its "local" acceptance and adaptation, and its generalisation in the population. This must be understood as a process where technological changes are in a constant negotiation, being permanently accepted and rejected.

Men had always helped in the domestic pottery production, although non-systematically working in the tasks, which did not demand a period of long learning and manual practice and, certainly, not in the ones which escaped to women socialisation. With the incorporation of workshops, this situation would not change. However, the access of men to the potter's wheel would turn them into manufacturers of base forms, under the service of women potters from different families. Women thus continued controlling the production process while men worked itinerantly, rotating among the different workshops with potter's wheels. This system has traditionally been interpreted as a male job, where the woman just helped to polish and decorate. However, I believe it was just the opposite: in this case, the man is the one who had to move to the potter's workshop and helped them to model basic forms faster.

The connections between male work on the one hand and the use of the potter's wheel, the origin of workshops and technological change on the other are not so evident. In fact, men had been incorporated into pottery production long before the potter's wheel appeared. And women had started to organise primitive workshops hiring workers even before the first structural technological modifications were evident. 
All this process should be framed within the process of social transformations between the 1930s and 1970s which aimed to solve specific problems within the context of local adaptations. This is such a situation where the incorporation of new actors and new information transmission networks would have played a fundamental role.

\section{References}

GUZMÁN, F, and TRAMPÉ, A., 1997. Cerámica artística de Lota Santiago de Chile: Lom.

ANDERS, M., CHANG, V., TOKUDA, L., QUIROZ, S., and SHIMADA, I., 1994. Producción cerámica del horizonte medio temprano en Maymí, Valle del Pisco, Perú. In: I. Shimada, ed. Tecnología y organización de la producción cerámica prehispánica en los Andes. Lima: Universidad Católica del Perú. Fondo Editorial, pp. 249-267.

VALDÉS, X., 2021. Archivo fotográfico del grupo de investigación género, historia y ruralidad de chile. Online. CEDEM Santiago de Chile. (Viewed at 10/10/2020). Avalaible from: https://www.generohistoriaruralidad.cl/ home.html

ARNOLD III, P. J., 1991. Domestic ceramic production and spatial organization: a Mexican case study in Ethnoarchaeology. Cambridge: Cambridge University Press.

ARNOLD, D., 1985. Ceramic theory and cultural process. New studies in Archaeology. Cambridge: Cambridge University Press.

ARNOLD, D., 1989. Patterns of learning residence and descent among potters in Ticul, Yucatan, Mexico. In: S. Shenan, ed. Approaches to cultural identity. London: Unwin Hyman, pp. 174-184.

BALFET, H., 1965. Ethnographical observations in North Africa and archaeological interpretation: The pottery of the Magreb. In: F. Matson, ed. Ceramics and Man. Chicago: Aldine, pp. 167-177.

BALFET, H., 1981. Production et distribution de poteries au Maghreb. In: T.H. Howard, and E.L. Morris, eds. Production and distribution: a ceramic viewpoint. Oxford: British Archaeological Reports - International Series, 120, pp. 271-283.

BARRALES, C., and VERGARA, M., 2008. Los alfareros de la cuenca del río Cachapoal. Rancagua: Primeros pasos ediciones.

BERG, L., DÍAZ, M., and BILBAO, M., 2014. Pomaire. Origen y destino de un pueblo alfarero. Documentos históricos. Santiago: Universidad de los Lagos.

BORDE, J., and GÓNGORA, M., 1956. Evolución de la propiedad rural en el Valle del Puangue. Santiago de Chile: Editorial Universitaria.

BOWEN, M., 2007. Estudio de identidad histórico-cultural, comunas del Monte, Isla de Maipo y Pomaire. Rutas del Sol. Santiago: Rutas del Sol.

CALVO, M., GARCÍA ROSSElló, J., JAVALOYAS, D., ALBERO, D. 2015. Playing with mud? An ethnoarchaeological approach to children's learning in Kusasi ceramic production. In: M. Sanchez Romero, E. Alarcon García, and G. Aranda Jimenez, eds. Children, identity and space. Oxford: Oxbow, pp. 88-104.

CHAVARRÍA, P., and VEGA SOTO, M.E., 2013. Entre gredas y adobes. Una aproximación a los oficios tradicionales y su valor en Coelemu y Quillón. Tomé: Ediciones CetSur.

COBO, J., 1964 (1653). Historia del Nuevo Mundo. Madrid: Biblioteca de Autores Españoles. Ed. Atlas.

LEÓN DE, K., MATTA, P., and VALDÉS, X., 1986. Loceras y trabajadoras de la arcilla de Pomaire. Santiago de Chile: Ediciones CEM.

DEAL, M., 1983., Pottery ethnoarchaeology among the Tzeltal Maya. Burbaby: Departament of Archaeology, Simon Fraser University.

ENCINA, F.A., 1945. Historia de Chile. Santiago: Editorial Nascimiento.

GARCÍA ROSSELLÓ, J., 2006. La producción cerámica en los valles centrales de Chile. In: Etnoarchaeology of the Prehistory: Beyond Analogy. Barcelona: CSIC, Institució Milà i Fontanals Barcelona, Departament d'arqueologia i antropologia, pp. 297-314.

GARCÍA ROSSELLÓ, J., 2007. La producción cerámica mapuche. Perspectiva histórica, arqueológica y etnográfica. In: VI Congreso Nacional de Antropología. Valdivia: Colegio de Antropólogos, Valdivia, pp. 1932-1946.
GARCÍA ROSSELLÓ, J., 2008. Etnoarqueología de la producción cerámica: Identidad y territorio en los valles centrales de Chile. Mayurqa, 32, Palma de Mallorca: UIB.

GARCÍA ROSSELLÓ, J., 2009. Tradición tecnológica y variaciones técnicas en la producción cerámica Mapuche. Complutum, 20(1), 153 171.

GARCÍA ROSSELLÓ, J., 2011. Modelado, aprendizaje y espacio social: Una reflexión desde la tecnología cerámica. Werkén, 14, 63-74.

GARCÍA ROSSELLÓ, J., 2016. ¡Que vienen las máquinas! Una historia de cambio tecnológico en la aldea alfarera de Pomaire (Chile). Anales del Museo de América, 14, 122-144.

GARCÍA ROSSELLÓ, J., 2019. Práctica técnica y práctica social en la producción cerámica del centro de Chile. Menga, 4, 60-76.

GARCÍA ROSSELLÓ, J., 2017. La tecnología cerámica como instrumento de construcción de la identidad de género: el caso de Quinchamalí. In: $L a$ trama de los objetos. Distintas miradas sobre cultura material. Santiago: Centre for Intercultural and Indigenous Research, Pontificia Universidad Católica de Chile, pp. 125-138.

GARCÍA ROSSELLÓ, J., 2019. Hands to the potter's Wheel: a Case of technological Change in Pottery production (Pomaire, Chile). In: C. Burke, and S. Spencer-Wood, eds. Crafting in the world, materiality in the Making. Switzerland: Springer, pp. 215-229.

GONZALEZ URQUIJO, J., IBAÑEZ ESTEVEZ, J.J., ZAPATA PEÑA, L., and PEÑA CHOCARRO, L., 2001. Estudio etnoarqueológico sobre la cerámica Gazua (Marruecos). Técnica y contexto social de un artesanado arcaico. Trabajos de Prehistoria, 58(1), 5-27.

GRAHAM, M., 1823. Diario de su residencia en Chile (1922) y su viaje a Brasil (1923). Madrid: Editorial Americana.

HENRIQUEZ, M., REYES, V., POPOVIC, V., and ALAMOS, I., 2013. Cerámicas y Vidrios. Colección del Museo Regional de Rancagua. Santiago: Ediciones FONDART.

LAGO, T., 1971. Arte popular chileno. Santiago de Chile: Editorial universitaria.

LYONS, D., and CASEY, J., 2016. It's a material world: the critical and ongoing value of ethnoarchaeology in understanding variation, change and materiality. World Archaeology, 48(5), 609-627.

MÁRQUEZ, B., 2014. Cerámica en penco. Industria y Sociedad 1888 1962. Concepción: Ediciones del Archivo Histórico de Concepción.

MONTT, S., and LECREC, C., 2017. Greda Viva, Estado Actual del pueblo alfarero de Pomaire: Testimonios de sus Artesanos. Santiago de Chile: Fondo nacional de Desarrollo Cultural y las Artes y FUCOA.

PEREZ, A., 1973. Artesanía y desarrollo: un plan para la comunidad de Pomaire. Santiago: Universidad de Chile.

POLITIS, G., 2015. Reflections about Contemporary Ethnoarchaeology. Pyrenae, 46(1), 41-83.

PRADO, C., ALCORTA, G., and OCARANZA, F., 2015. La producción alfarera en la ollería de los jesuitas de Santiago, Chile (siglos XVIIXVIII). Trabajo y Sociedad, 24, 249-265.

PRIETO, C., BAEZA, J., RIVERA, F., and RIVAS, P., 2006. Estudios cerámicos en la catedral metropolitana, aportes a la arqueología histórica de Santiago de Chile. In: Actas del XVII Congreso Nacional de Arqueología Chilena. Valdivia: Universidad Austral de Chile, pp.10251036

REBOLLEDO, L., 1994. Mujeres y artesanía. Pomaire de aldea campesina a pueblo alfarero. Revista ERUE, 20(59), 47-59.

RENFREW, C., 1978. The anatomy of innovation, In: D. Green et al., eds. Social organisation and settlement. Oxford: British Archaeological Reports - International Series, 47, 89-117.

RICE, P.M., 1987. Pottery analysis: a sourcebook. Chicago: University of Chicago Press.

SAGREDO, R., 2014. Historia mínima de Chile. Madrid: Turner.

SALAZAR, G., 2015. El proceso económico. Chile 1880/1930. Santiago: Taurus.

VALDES, X., and MATTA, P., 1986. Oficios y trabajos de las mujeres de Pomaire. Santiago de Chile: CEM. Pehuén.

VALENZUELA ROJAS, B., 1955. La cerámica folklórica de Pomaire. Archivos de Folklore Chileno, 6-7, 28-60.

VIDAL, A., and GARCÍA ROSSELLÓ, J., 2009. Dime cómo lo haces: una visión etnoarqueológica de las estrategias de aprendizaje de alfarería tradicional. Arqueoweb, 12. (viewed at 10/10/2020). Available from: https://webs.ucm.es/info/arqueoweb/pdf/12/vidal.pdf 
